\title{
Demonstrating the presence of Ehrlichia canis DNA from different tissues of dogs with suspected subclinical ehrlichiosis
}

\author{
Carlos A. Rodríguez-Alarcón ${ }^{1}$ (10, Diana M. Beristain-Ruiz ${ }^{1 *}$, Angélica Olivares-Muñoz², \\ Andrés Quezada-Casasola', Federico Pérez-Casio', Jesús A. Álvarez-Martínez³, Jane Tapia-Alanís', \\ José J. Lira-Amaya ${ }^{3}$, Ramón Rivera-Barreno ${ }^{1}$, Orlando S. Cera-Hurtado ${ }^{1}$, José A. Ibancovichi-Camarillo ${ }^{4}$, \\ Luis Soon-Gómez ${ }^{5}$, Jaime R. Adame-Gallegos ${ }^{6}$ and Julio V. Figueroa-Millán ${ }^{3}$
}

\begin{abstract}
Background: Nowadays, Ehrlichia canis receives increasing attention because of its great morbidity and mortality in animals. Dogs in the subclinical and chronic phases can be asymptomatic, and serological tests show cross-reactivity and fail to differentiate between current and past infections. Moreover, there could be low parasitaemia, and E. canis might be found only in target organs, hence causing results to be negative by polymerase chain reaction (PCR) on blood samples.
\end{abstract}

Methods: We evaluated by PCR the prevalence of E. canis in blood, liver, spleen, lymph node and bone marrow samples of 59 recently euthanised dogs that had ticks but were clinically healthy.

Results: In total, $52.55 \%$ of the blood PCRs for E. canis were negative, yet $61.30 \%$ yielded positive results from tissue biopsies and were as follows: $63.15 \%$ from bone marrow; $52.63 \%$ from liver; $47.36 \%$ from spleen; and $15.78 \%$ from lymph node. In addition, 33\% had infection in three tissues (spleen, liver and bone marrow).

Conclusions: Our results show the prevalence of E. canis from tissues of dogs that were negative by blood PCR. Ehrlichia canis DNA in tissue was 30\% lower in dogs that tested negative in PCR of blood samples compared to those that were positive. However, it must be taken into account that some dogs with negative results were positive for E. canis in other tissues.

Keywords: Ehrlichia canis, Biopsies, Spleen, Bone marrow, Liver, Lymph node

\section{Background}

Canine monocytic ehrlichiosis (CME) is caused by Ehrlichia canis, an intracellular parasitic bacterium and tickborne pathogen. Recently, this pathogen has received further attention because it has led to increasing morbidity and mortality in animals [1]. Transmission is mediated

\footnotetext{
*Correspondence: diana.beristain@uacj.mx

1 Veterinary Science Department, Universidad Autónoma de Ciudad Juárez, Anillo Envolvente y Estocolmo s/n, Zona PRONAF, 32310 Juárez, México

Full list of author information is available at the end of the article
}

by the tick Rhipicephalus sanguineus (sensu lato), and, before infection, the bacteria replicate in monocytes and macrophages [2].

Clinical presentation of CME results in acute, chronic or subclinical phases, with several clinical manifestations. The acute phase persists for 2-4 weeks [3] and is characterised by signs in diverse systems, yet the most common are fever, weight loss, anorexia, depression, lymphadenomegaly, splenomegaly and vasculitis [4]. In addition, dogs in this phase show thrombocytopenia as the most common laboratory abnormality [5]. In the subclinical phase,

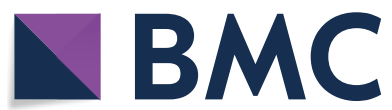

(c) The Author(s) 2020. This article is licensed under a Creative Commons Attribution 4.0 International License, which permits use, sharing, adaptation, distribution and reproduction in any medium or format, as long as you give appropriate credit to the original author(s) and the source, provide a link to the Creative Commons licence, and indicate if changes were made. The images or other third party material in this article are included in the article's Creative Commons licence, unless indicated otherwise in a credit line to the material. If material is not included in the article's Creative Commons licence and your intended use is not permitted by statutory regulation or exceeds the permitted use, you will need to obtain permission directly from the copyright holder. To view a copy of this licence, visit http://creativecommons.org/licenses/by/4.0/. The Creative Commons Public Domain Dedication waiver (http//creativecommons.org/publicdomain/zero/1.0/) applies to the data made available in this article, unless otherwise stated in a credit line to the data. 
dogs have persistent thrombocytopenia and leukopenia in laboratory analysis; however, during this stage, in some dogs the thrombocytopenia may be mild to nonexistent [6], and they usually do not show clinical signs. The duration of this phase varies from months to years [7]. Additionally, during this phase it is common that the microorganism may not circulate in the blood but is deposited in some target organ, such as the spleen, bone marrow or liver [8-11]. Furthermore, previous research has shown that $E$. canis is widely distributed in different organs of infected dogs $[8,9,12,13]$. Otherwise, in the chronic phase dogs show severe pancytopenia, haemorrhagic diathesis, and general debilitation [3]. Immune system deficiency, stress, co-infections, virulence strain, and geographical region are factors that influence the presentation of this phase in affected dogs [8].

In recent times, diagnosis of the disease has been challenging for practicing veterinarians [14, 15]. Identification of morulae in monocytes in a blood smear is diagnostic of the disease; however, a low frequency of morulae in buffy coat smears has previously been reported, which could be due to the low parasitaemia observed in the natural infection [7, 11, 16-21]. Besides, other more specific methods are used as diagnostics, including the immunofluorescence antibody test (IFA) and ELISA (enzyme-linked immunosorbent assay), which are both able to detect specific antibodies [21-27], as well as other molecular techniques such as the polymerase chain reaction (PCR) $[1,19,28-36]$. Presently, the Infectious Disease Group of the American College of Veterinary Internal Medicine (ACVIM) requires that dogs diagnosed with this disease show suggestive clinical signs and have positive tests, either by serology and/or by PCR [37]. A complication in the diagnosis comes about in dogs in the subclinical phase of the disease because dogs normally do not show clinical signs. Furthermore, crossreactivity and a failure to differentiate between current and past infections with ELISA and IFA tests has been reported $[25,38,39]$. On the other hand, both in the subclinical and chronic phases, there is a possibility that parasitaemia is low in the $\operatorname{dog}[20,26,40,41]$, as the bacteria are located in the target organs [10]. Therefore, in these cases, the dogs will be negative in a PCR blood test [10].

Presently, the presence of the DNA of E. canis in several tissues, such as blood, bone marrow, spleen, liver, kidney and lymph nodes has been demonstrated by PCR in experimentally infected dogs $[7,8,11,12,40]$.

The goal of this study was to evaluate the occurrence of E. canis in different tissues, such as liver, spleen, lymph nodes and bone marrow, in dogs naturally infected with monocytic ehrlichiosis, assuming that a considerable percentage of dogs negative to E. canis by blood PCR will show positive results in biopsies of different tissues.

\section{Methods}

An analysis of the variation in infection by $E$. canis in four tissues was carried out in two groups of dogs: positive and negative by PCR of blood samples.

\section{Animals}

Fifty-nine dogs obtained from the municipal AntiRabies Centre of Juárez were used in this study. Based on the Centre's internal regulations, animals that were not adopted 8 weeks after their arrival were euthanised. Euthanasia was performed by an overdose of sodium pentobarbital according to national and international animal welfare regulations.

In order to increase the possibility that dogs will present the subclinical phase of the disease, the inclusion criteria were that the dogs should have ticks but be clinically healthy; therefore, dogs without ticks or with signs of any disease were excluded.

\section{Sample collection}

Whole blood samples were collected in tubes containing EDTA (Vacutainer BD ${ }^{\circledR}$, Mexico City, Mexico) by cephalic venepuncture with prior administration of sodium pentobarbital. The other tissue samples were acquired by biopsies immediately after euthanasia, following the steps of surgical asepsis in order to prevent cross-contamination. In addition, with the same purpose, a change of instruments was made for the biopsy of each tissue, and particular attention was taken to avoid blood or other fluid from the dog coming into contact with the tissue samples.

Bone marrow aspirates were obtained with bone marrow aspiration needles (Argon Medical Devices ${ }^{\circledR}$, Dallas, TX, USA) from the greater tubercle of the humerus, as described by Raskin \& Messickin [42]. Hepatic and splenic biopsies were obtained by celiotomy and with the ligature fracture technique [43]. Finally, prescapular lymph node were biopsied with a biopsy punch (Premier $^{\circledR}$, Plymouth Meeting, PA, USA) as previously described [44]. Tissues samples were marked and frozen at $-20^{\circ} \mathrm{C}$ for future extraction of DNA and PCR analysis.

Biopsies obtained from spleen, liver and lymph node had an average weight of $200 \mathrm{mg}$ (range 150-210 mg). The amount of whole blood obtained was $1.5 \mathrm{ml}$ and the bone marrow biopsy obtained $0.6 \mathrm{ml}$ on average (range $0.4-0.7 \mathrm{ml})$

\section{DNA extraction}

For the blood samples, the extraction of genomic DNA from the cellular package of the dogs' samples was performed using the UltraClean Blood DNA Isolation Kit (MoBio Lab ${ }^{\circledR}$, Carlsbad, CA, USA), according to the manufacturer's instructions. 
The other tissues were handled in a sterile fashion prior to the extraction of DNA. For the extraction of DNA from the biopsies, the protocol was modified with the previous addition of lysis reagents [45]. The tissues were then macerated with the use of a low-velocity drill (Jorvet Lab $^{\circledR}$, Loveland, CO, USA) and a dental burn (JOTA Technical $^{\circledR}$, Rüthi, Switzerland). Once each tissue was macerated, DNA extraction was performed in the same way as for the blood.

\section{PCR amplification and analysis}

Detection of $E$. canis DNA was achieved with the use of nested PCR molecular test. Initially, to amplify the Ehrlichia spp. $16 S$ rRNA gene, 2 pmol of primers ECC (5"AGA ACG AAC GCT GGC GGC CAA GC- $3^{\prime}$ ) and ECB (5'-CGT ATT ACC GCG GCT GCT-3') were used [28]. In the second PCR, to amplify the E. canis $16 S$ rRNA gene, 2 pmol of primer HE-3(5'-TAT AGG TAC CGT CAT TAT CTT CCC TAT- $3^{\prime}$ ) combined with the reverse primer ECA (5'-CAA TTA TTT ATA GCC TCT GGC TAT AGG AA-3') were used $[28,46]$.

Initially, the PCR was performed in a thermocycler (Bio-Rad ${ }^{\circledR}$ C-1000 Touch, Hercules, CA, USA) starting at $94{ }^{\circ} \mathrm{C}$ for $1 \mathrm{~min}$ followed by 35 cycles of $94{ }^{\circ} \mathrm{C}$ for 1 min (denaturation), $60{ }^{\circ} \mathrm{C}$ for $1 \mathrm{~min}$ (hybridisation) and $72{ }^{\circ} \mathrm{C}$ for $3 \mathrm{~min}$ (extension). This was followed by $94{ }^{\circ} \mathrm{C}$ for $5 \mathrm{~min}$ and then 40 cycles of $94^{\circ} \mathrm{C}$ for $1 \mathrm{~min}$ (denaturation), $60^{\circ} \mathrm{C}$ for $1 \mathrm{~min}$ (hybridisation), and $72^{\circ} \mathrm{C}$ for $1 \mathrm{~min}$ (extension), as described previously [28, 46, 47].

\section{Statistical analyses}

A multivariate logistic regression model was used for the response variable 'infection' which was binary (dummy variable) with $\mathrm{y}=1$ if positive, and $\mathrm{y}=0$ if negative, depending on two explanatory variables: blood positivity (two levels) and positivity in four separate tissues (four levels). Therefore, the model was: infection $=$ blood + tissue + error.

The model analysed separately infection in both groups of dogs. In each group, the model compared infection among the four tissues using statistical tests ' $\mathrm{z}$ ' between pairs of tissues, using a multiple-comparison Scheffe test.

Comparison of the proportions of positive and negative results in blood, lymph node, liver and spleen samples were performed using Chi square and Fisher's exact tests with the FREQ procedure of SAS (9.0). Significance was considered with a $P$-value of $<0.05$.

\section{Results}

Of the 59 dogs analysed in this study, 28 (47.45\%) showed a positive result for E. canis by PCR of blood samples, and $31(52.55 \%)$ were negative. When evaluating the
28 dogs that were positive by PCR of blood samples, it was observed that $16(57.14 \%)$ were also positive by PCR of some of the tissues. Otherwise, when analysing dogs with negative PCR results in blood $(n=31)$ and comparing them with the results of PCR in different tissues of the same dogs, it was observed that 19 dogs $(61.30 \%)$ presented positive results for $E$. canis in some of the tissues and $12(38.70 \%)$ were negative in all tissues biopsied.

The tissue biopsy with the highest number of positive samples was the bone marrow, with 26 (44.60\%). Positive results from bone marrow samples occurred in both positive and negative blood samples. For example, 10 dogs (35.71\%) that were positive by PCR of blood samples were also positive in PCR of the bone marrow (Table 1). Furthermore, it was found that 12 of 19 cases $(63.15 \%)$ were positive with negative PCR of blood samples (Table 2). In half of the negative cases $(n=6)$, the results of the PCR of other tissues were negative. Conversely, in two cases, the PCR was positive for all tissues analysed.

The tissue with the second highest number of positive results was the spleen, with a prevalence of $42.37 \%$ $(n=25)$. When analysing PCR-positive blood samples, 16 samples (57.14\%) were also positive in PCR of spleen (Table 1). In blood PCR-negative dogs, the splenic tissue showed $9(47.36 \%)$ positive PCR results, although there were spleen-only positive samples on two occasions (Table 2). Also, on two occasions the PCR was positive for all the tissues analysed. The remaining of the combinations are presented in Tables 1 and 2 .

The liver had 22 PCR-positive cases (37.28\%) from the total samples evaluated. Of the PCR-positive blood samples, 12 (42.85\%) were also positive for the liver tissue (Table 1). Similarly, with the spleen, of the 19 PCRnegative blood samples, 10 (52.63\%) were positive for the liver tissue. In the negative blood samples, there was one liver-only positive result (Table 2). In addition, the PCR was positive in all tissues twice. Finally, the tissue with the fewest positive results in the study was the lymph node, with 5 cases $(8.47 \%)$. In the PCR-positive blood samples, only 2 cases were positive $(10.52 \%$; Table 1). On the other hand, the blood samples negative by PCR were positive for lymphatic tissue in 3 cases, representing $15.78 \%$. In none of these three cases was the lymph node the only tissue with positive results (Table 2).

Considering infection in the four tissues, the infection rate was the same in both negative and positive dogs in PCR of blood samples $(P>0.05)$. The infection in tissues of negative dogs was an average rate of $0.23 \pm$ 0.05 , and for positive dogs was $0.35 \pm 0.04(d f=233, P$ $<0.001)$. 
Table 1 Comparison between positive blood-PCR of E. canis and the $P C R$ results in other tissues

\begin{tabular}{|c|c|c|c|c|}
\hline Blood PCR & $\begin{array}{l}\text { Bone } \\
\text { marrow PCR }\end{array}$ & Spleen PCR & Liver PCR & $\begin{array}{l}\text { Lymph } \\
\text { node } \\
\text { PCR }\end{array}$ \\
\hline+ & + & + & + & - \\
\hline+ & + & + & + & - \\
\hline+ & + & + & + & + \\
\hline+ & + & + & + & + \\
\hline+ & - & + & + & - \\
\hline+ & + & + & + & - \\
\hline+ & + & + & + & - \\
\hline+ & - & + & + & - \\
\hline+ & + & + & + & - \\
\hline+ & + & + & + & - \\
\hline+ & - & + & + & - \\
\hline+ & - & + & - & - \\
\hline+ & - & - & - & - \\
\hline+ & - & + & - & - \\
\hline+ & + & - & - & - \\
\hline+ & + & - & - & - \\
\hline+ & + & + & - & - \\
\hline+ & - & - & - & - \\
\hline+ & + & - & - & - \\
\hline+ & - & - & - & - \\
\hline+ & - & - & - & - \\
\hline+ & - & + & - & - \\
\hline+ & - & - & - & + \\
\hline+ & + & + & + & - \\
\hline+ & - & - & - & - \\
\hline+ & - & - & - & - \\
\hline+ & - & - & - & - \\
\hline+ & - & - & - & - \\
\hline
\end{tabular}

\section{Discussion}

In the present study, of the 59 clinically healthy dogs analysed, $47.45 \%$ had a positive result for E. canis with PCR of blood samples. In addition, PCR recognised a higher prevalence of $E$. canis in different tissues of naturally infected dogs, in those with both positive and negative results by PCR of blood samples. With these results it was demonstrated that some dogs suspected of presenting subclinical ehrlichiosis, presented E. canis DNA in various tissues, even though they had negative PCR results from blood.

At the present time, diagnosis by PCR is more useful than serology for the differentiation of concurrent infections and co-infections with diverse Ehrlichia spp. and is used for treatment monitoring [46]. However, in naturally-occurring $\mathrm{CME}$, the diagnostic sensitivity and
Table 2 Comparison between negative blood-PCR of E. canis and PCR results in other tissues

\begin{tabular}{|c|c|c|c|c|}
\hline Blood PCR & $\begin{array}{l}\text { Bone } \\
\text { marrow PCR }\end{array}$ & Spleen PCR & Liver PCR & $\begin{array}{l}\text { Lymph } \\
\text { node } \\
\text { PCR }\end{array}$ \\
\hline- & - & + & + & - \\
\hline- & - & + & + & - \\
\hline- & - & - & - & - \\
\hline- & - & + & + & - \\
\hline- & + & + & + & + \\
\hline- & + & - & + & + \\
\hline- & - & - & - & - \\
\hline- & + & + & + & - \\
\hline- & + & - & - & - \\
\hline- & - & - & - & - \\
\hline- & - & + & - & - \\
\hline- & + & + & + & - \\
\hline- & + & + & + & + \\
\hline- & - & - & - & - \\
\hline- & - & - & - & - \\
\hline - & - & - & - & - \\
\hline - & - & + & - & - \\
\hline- & - & - & - & - \\
\hline - & - & - & - & - \\
\hline - & + & - & - & - \\
\hline- & + & - & + & - \\
\hline- & - & - & - & - \\
\hline - & + & - & - & - \\
\hline- & - & - & - & - \\
\hline- & + & - & - & - \\
\hline- & - & - & - & - \\
\hline- & + & - & - & - \\
\hline- & - & - & - & - \\
\hline
\end{tabular}

Key: + , positive; -, negative

optimal tissue for PCR testing in the untreated dog or in the post-treatment setting has not yet been clarified [46]. Results obtained at this point demonstrate that in dogs with naturally-occurring CME infection it is feasible to detect $E$. canis in different tissues, even if they have negative blood tests. Additionally, in the acute phase of infection, E. canis is easily detected in blood, while in the subclinical and chronic phases there is the possibility of false negatives. Therefore, some tissues are more appropriate for sampling, such as the bone marrow and the spleen $[8,9,13,48]$, an argument that has been corroborated by the present investigation. This study does not suggest performing tissue PCR for routine diagnosis of CME in dogs because performing biopsies in dogs with no clinical signs is impractical. 
However, sampling tissues may be relevant in understanding the distribution of CME in dogs.

Comparative information on the spread and presence of $E$. canis by PCR analysis in multiple organs is limited, especially in dogs with the natural form of the disease, although some research has been done in experimentally inoculated dogs. For example, it is proven that PCR is effective in detecting $E$. canis in diverse tissues of dogs with experimental disease [12]. In the same way, it has been described that the spleen is a tissue that can be useful to demonstrate the presence of $E$. canis DNA by PCR $[8,9]$. In addition, the possibility of dogs in the subclinical phase being negative to PCR in blood samples and positive to PCR of splenic aspirates has also been established [8]. Splenic aspirates have previously been performed to detect E. canis DNA by PCR. Previous research has shown that dogs that were blood-positive were also positive to splenic aspirates, compared to those that were negative in blood [7]. These results differ from those obtained in the present investigation, where a prevalence of $42.37 \%(n=25)$ was obtained. Furthermore, of the 19 blood PCR-negative dogs, nine (47.36\%) were positive by PCR in the splenic biopsies.

It has been revealed that in the acute phase of disease, splenic aspirates are not superior to blood samples for detection of ehrlichial DNA by PCR. However, splenic aspirates are superior to blood in the evaluation of the response to therapy in experimentally treated dogs, because $E$. canis DNA could be detected in the spleen after its elimination from the blood [8].

The results of the present study also differ from previous reports in which the number of dogs positive and negative for $E$. canis by PCR is similar in blood samples and splenic aspirates. The results revealed that DNA of E. canis was isolated in 29 (72.5\%) spleen samples and in 30 (75\%) whole blood samples; and ehrlichial DNA was not isolated in $11(27.5 \%)$ spleen samples and in 10 (25\%) whole blood samples [10].

The difference between the other studies and the present investigation is the spleen tissue analysed. In our study, DNA was obtained through splenic biopsy, whereas in others DNA was obtained from blood through splenic aspirates. In another investigation, it was found that out of 78 dogs with splenic disease, only one was positive for E. canis by PCR in a splenic biopsy [49]. The present study creates the expectation of performing research to establish the most suitable technique to obtain $E$. canis DNA from the spleen in dogs by comparing splenic aspirates with biopsies, including those taken with minimally invasive techniques, such as ultrasound-guided or laparoscopic methods.

Furthermore, another important difference in our study is that the tissue with the highest number of positive samples was the bone marrow, in contrast to a previous report that obtained more positives from aspirates of the spleen [8]. Nevertheless, other studies have demonstrated that other tissues besides the spleen are better in detecting $E$. canis by PCR. For example, some authors describe results similar to those obtained in the present study and show that E. canis DNA was most often amplified from bone marrow [50, 51]. But, in these cases, there was experimental disease, and PCR was performed using aspirates. On the other hand, in one study on biopsies of dog cadavers, contrary to the results of the present study, none of the bone marrow biopsies was positive for E. canis by PCR [10].

An important limitation of the present study was the absence of blood analysis, especially blood counts. This could have established in a more accurate way the dogs presenting with the subclinical phase of monocytic ehrlichiosis [46]. However, it can be assumed that positive dogs were in this phase, since they were clinically healthy.

Ehrlichia canis is widespread throughout the different body systems of infected dogs. In addition, the molecular detection of $E$. canis DNA has shown that it can be present in different target organs [13, 52, 53]. In the subclinical and chronic phases, E. canis could be 'hiding' in splenic macrophages [8]. In this case, the spleen may be the principal reservoir of $E$. canis, probably because it has an abundance of macrophages. Moreover, some studies propose that it is the last organ to contain the microorganism before its elimination [8, 54]. Therefore, when containing a large number of bacteria, the spleen is considered by some authors as the organ of choice for molecular detection in different phases of the disease $[4,8,48$, 55]. Although in our study E. canis DNA was detected in the spleen, our results differ slightly from this statement, since it was the third most affected organ, surpassed by the bone marrow and liver. However, our results are similar to those of other studies that suggested that the spleen was inferior when compared to other tissues [10, 12, 49, 50].

\section{Conclusions}

In conclusion, results of this study could be applicable in some cases where the diagnostic sensitivity of PCR may be suboptimal [46]. In some special cases, it will be necessary to search for $E$. canis DNA in different organs by molecular methods. In this study we have demonstrated that although infection in organs was 30\% lower in dogs negative by PCR on blood samples, a considerable number of dogs $(n=19$ or $61.30 \%)$ showing negative results by blood PCR were positive for E. canis in some organs. Dogs with positive blood results were positive in three 
tissues (liver, bone marrow and spleen) in $48 \%$ of cases. At the same time, these three tissues were more positive than the lymph node, which was positive in only $8 \%$ of the samples evaluated, and was four times lower than in any of the other three tissues. Dogs with negative results in blood showed 33\% detection of E. canis DNA in the spleen, liver and bone marrow; however, the presence of DNA was higher in liver and bone marrow than in the lymph node. Because in some cases DNA was detected in only one of these tissues, it is proposed that biopsies be performed of at least these three. This assertion is stipulated for other rickettsial diseases, such as Anaplasma spp., where blood samples are routinely used for screening, but in persistently infected dogs with intermittent or low-level bacteraemia other tissues might be useful [56]. The results open the possibility of performing similar research aimed at detecting E. canis by PCR of different tissues in treated dogs that continue to show signs or alterations in blood tests, as well as in dogs that show signs suggestive of the disease but have negative results in serological and molecular blood analyses.

\section{Abbreviations \\ ACVIM: American College of Veterinary Internal Medicine; DNA: deoxyribo- nucleic acid; CME: canine monocytic ehrlichiosis; EDTA: ethylenediaminetet- raacetic acid; ELISA: enzyme-linked immunosorbent assay; IFA: immunofluo- rescence antibody test; PCR: polymerase chain reaction.}

\section{Acknowledgements}

The authors would like thank to DVM Benn Tonderai Katsamudanga for checking the spelling and grammar.

\section{Authors' contributions}

CARA, DMBR and JVFM conceived and designed the study. CARA, AOM, JTA, RRB and LSG collected samples and participated in data collection. DMBR, JAAM, JTA, JJLA OSCH and JVFM handled tissue samples, extracted DNA and performed PCR in the laboratory. AQC, FPC and JAl analysed the data. CARA, AOM and JRAG wrote the manuscript. All authors read and approved the final manuscript.

\section{Funding}

Funding to support this study was received from CONACYT/INFR 2014-224673 and PRODEP-SEP.

\section{Availability of data and materials}

The data supporting the conclusions of this article are included within the article and its additional files. Raw data used or analysed during the present study are available from the corresponding author upon reasonable request.

\section{Ethics approval and consent to participate}

This study was reviewed and approved by the Ethics and Animal Welfare Committee of the Universidad Autónoma de Ciudad Juárez, Mexico (CBE. ICB/001.01-25). The handling of animals was carried out based on the regulation of laboratory animal handling and animal welfare (NORMA Oficial Mexicana NOM-062-ZOO-1999) and in accordance with the International Guiding Principles for Biomedical Research Involving Animals.

\section{Consent for publication}

Not applicable.

\section{Competing interests}

The authors declare that they have no competing interests.

\section{Author details}

${ }^{1}$ Veterinary Science Department, Universidad Autónoma de Ciudad Juárez, Anillo Envolvente y Estocolmo s/n, Zona PRONAF, 32310 Juárez, México. ${ }^{2}$ Veterinary and Zootechnic Faculty, Universidad Veracruzana, Miguel Ángel de Quevedo s/n esq. Yáñez, Col. Unidad Veracruzana, 91710 Veracruz, México. ${ }^{3}$ CENID-Salud Animal e Inocuidad. INIFAP, Km. 11.5 de la Carretera Federal Cuernavaca-Cuautla, 62550, Col. Progreso, Jiutepec, México. ${ }^{4}$ Department of Veterinary Anesthesia, Analgesia and Pharmacology, Faculty of Veterinary Medicine, Universidad Autónoma del Estado de México, El Cerrillo Piedras Blancas, 50090 Toluca, México. ${ }^{5}$ Municipal Anti-Rabies Center, Jurisdicción Sanitaria II, Servicios de Salud de Chihuahua, Calle Sevilla 4241, Colonia San Antonio, 32250 Juárez, México. ${ }^{6}$ Faculty of Chemistry, Universidad Autónoma de Chihuahua, Campus 2, Circuito Universitario s/n, 31125 Chihuahua, México.

Received: 8 February 2020 Accepted: 15 September 2020

Published online: 15 October 2020

\section{References}

1. Bunroddith K, Viseshakul N, Chansiri K, Lieberzeit P. QCM-based rapid detection of PCR amplification products of Ehrlichia canis. Anal Chim Acta. 2017;1001:106-7.

2. Dilipkumar D. Clinico, haemato-biochemical changes and therapeutic management of canine ehrlichiosis. 2018;7:101-6

3. Harrus S, Waner T. Diagnosis of canine monocytotropic ehrlichiosis (Ehrlichia canis): an overview. Vet J. 2011:187:292-6.

4. Malik Ml, Qamar M, Ain Q, Hussain MF, Dahmani M, Ayaz M, et al. Molecular detection of Ehrlichia canis in dogs from three districts in Punjab (Pakistan). Vet Med Sci. 2018;4:126-32.

5. Bulla C, Takahira RK, Araújo JP Jr, AparecidaTrinca L, Lopes RS, Wiedmeyer CE. The relationship between the degree of thrombocytopenia and infection with Ehrlichia canis in an endemic area. Vet Res. 2004;35:141-6.

6. Waner T, Harrus S, Bark H, Bogin E, Avidar Y, Keysary A. Characterization of the subclinical phase of canine ehrlichiosis in experimentally infected beagle dogs. Vet Parasitol. 1997;69:307-17.

7. Harrus S, Waner T, Aizenberg I, Foley JE, Poland AM, Bark H. Amplification of ehrlichial DNA from dogs 34 months after infection with Ehrlichia canis. J Clin Microbiol. 1998;36:73-6.

8. Harrus S, Kenny M, Miara L, Aizenberg I, Waner T, Shaw S. Comparison of simultaneous splenic sample PCR with blood sample PCR for diagnosis and treatment of experimental Ehrlichia canis infection. Antimicrob Agents Chemother. 2004;48:4488-90.

9. Gal A, Loeb E, Yisaschar-Mekuzas Y, Baneth G. Detection of Ehrlichia canis by PCR in different tissues obtained during necropsy from dogs surveyed for naturally occurring canine monocytic ehrlichiosis. Vet J. 2008;175:212-7.

10. Faria JLM, Dagnone AS, Munhoz TD, João CF, Pereira WAB, Machado RZ, et al. Ehrlichia canis morulae and DNA detection in whole blood and spleen aspiration samples. Rev Bras Parasitol Vet. 2010;19:98-102.

11. Iqbal Z, Rikihisa Y. Application of the polymerase chain reaction for the detection of Ehrlichia canis in tissues of dogs. Vet Microbiol. 1994:42:281-7.

12. Mylonakis $M E$, Koutinas $A F, B$ reitschwerdt $E B$, Hegarty $B C$, Billinis $C D$, Leontides LS, et al. Chronic canine ehrlichiosis (Ehrlichia canis): a retrospective study of 19 natural cases. J Am Anim Hosp Assoc. 2004;40:174-84.

13. Greene CE. Infectious diseases of the dog and cat. Infect Dis Dog Cat. 2006;2:676-85.

14. René-Martellet M, Lebert I, Chêne J, Massot R, Leon M, Leal A, et al. Diagnosis and incidence risk of clinical canine monocytic ehrlichiosis under field conditions in southern Europe. Parasit Vectors. 2015;8:3.

15. Baneth G, Bourdeau P, Bourdoiseau G, Bowman D, Breitschwerdt E, Capelli $\mathrm{G}$, et al. Vector-borne diseases - constant challenge for practicing veterinarians: recommendations from the CVBD World Forum. Parasit Vectors. 2012;5:55.

16. Elias E. Diagnosis of ehrlichiosis from the presence of inclusion bodies or morulae of E canis. J Small Anim Pract. 1992;33:540-3. 
17. Frank JR, Breitschwerdt EB. A retrospective study of ehrlichiosis in 62 dogs from North Carolina and Virginia. J Vet Intern Med. 1999;13:194-201.

18. Mylonakis ME, Koutinas AF, Billinis C, Leontides LS, Kontos V, Papadopoulos $\mathrm{O}$, et al. Evaluation of cytology in the diagnosis of acute canine monocytic ehrlichiosis (Ehrlichia canis): a comparison between five methods. Vet Microbiol. 2003;91:197-204.

19. Ramos CAN, Ramos RAN, Araújo FR, Guedes DS, Souza IIF, Ono TM, et al. Comparison of nested-PCR with blood smear examination in detection of Ehrlichia canis and Anaplasma platys in dogs. Rev Bras Parasitol Vet. 2009;18:58-62.

20. Bai L, Goel P, Jhambh R, Kumar P, Joshi VG. Molecular prevalence and haemato-biochemical profile of canine monocytic ehrlichiosis in dogs in and around Hisar, Haryana, India. J Parasit Dis. 2017:41:647-54.

21. Kottadamane MR, Dhaliwal PS, Singla L, Bansal BK, Uppal SK. Clinical and hematobiochemical response in canine monocytic ehrlichiosis seropositive dogs of Punjab. Vet World. 2017;10:255-61.

22. Harrus S, Alleman AR, Bark H, Mahan SM, Waner T. Comparison of three enzyme-linked immunosorbant assays with the indirect immunofluorescent antibody test for the diagnosis of canine infection with Ehrlichia canis. Vet Microbiol. 2002;86:361-8.

23. O'Connor TP, Hanscom JL, Hegarty BC, Groat RG, Breitschwerdt EB. Com parison of an indirect immunofluorescence assay, western blot analysis, and a commercially available ELISA for detection of Ehrlichia canis antibodies in canine sera. Am J Vet Res. 2006;67:206-10.

24. Maazi N, Malmasi A, Shayan P, Nassiri SM, Salehi TZ, Fard MS. Molecular and serological detection of Ehrlichia canis in naturally exposed dogs in Iran: an analysis on associated risk factors. Rev Bras Parasitol Vet. 2014;23:16-22.

25. Maggi RG, Birkenheuer AJ, Hegarty BC, Bradley JM, Levy MG, Breitschwerdt EB. Comparison of serological and molecular panels for diagnosis of vector-borne diseases in dogs. Parasit Vectors. 2014;7:127.

26. Vrhovec MG, Pantchev N, Failing K, Bauer C, Travers-Martin N, Zahner H. Retrospective analysis of canine vector-borne diseases (CVBD) in Germany with emphasis on the endemicity and risk factors of leishmaniosis. Parasitol Res. 2017:116:131-44.

27. Wilkerson MJ, Black KE, Lanza-Perea M, Sharma B, Gibson K, Stone DM et al. Initial development and preliminary evaluation of a multiplex bead assay to detect antibodies to Ehrlichia canis, Anaplasma platys, and Ehrlichia chaffeensis outer membrane peptides in naturally infected dogs from Grenada, West Indies. J Vet Diagnostic Investig. 2017;29:109-14.

28. Vieira FT, Acosta ICL, Martins TF, Filho JM, Krawczak FS, Barbieri ARM, et al. Tick-borne infections in dogs and horses in the state of Espírito Santo. Southeast Brazil. Vet Parasitol. 2018;249:43-8.

29. Wen B, Rikihisa Y, Mott JM, Greene R, Kim HY, Zhi N, et al. Comparison of nested PCR with immunofluorescent-antibody assay for detection of Ehrlichia canis infection in dogs treated with doxycycline. J Clin Microbiol. 1997:35:1852-5.

30. Rosenstraus M, Wang Z, Chang SY, DeBonville D, Spadoro JP. An internal control for routine diagnostic PCR: design, properties, and effect on clinical performance. J Clin Microbiol. 1998;36:191-7.

31. Bélanger M, Sorenson HL, France MK, Bowie MV, Barbet AF, Breitschwerdt EB, et al. Comparison of serological detection methods for diagnosis of Ehrlichia canis infections in dogs. J Clin Microbiol. 2002;40:3506-8.

32. Aguirre E, Tesouro MA, Amusategui I, Rodríguez-Franco F, Sainz A. Comparison between different polymerase chain reaction methods for the diagnosis of Ehrlichia canis infection. Ann NY Acad Sci. 2008;1149:118-20.

33. Nakaghi ACH, Machado RZ, Costa MT, André MR, Baldani CD. Canine ehrlichiosis: clinical, hematological, serological and molecular aspects. Ciência Rural. 2008;38:766-70.

34. Rotondano TE, de Almeida AMP, Lustosa EMC, Cordeiro AA, Camboim EKA, de Azevedo SS, et al. An assessment of whole blood and fractions by nested PCR as a DNA source for diagnosing canine ehrlichiosis and anaplasmosis. Sci World J. 2012;2012:605743.

35. Starkey LA, Barrett AW, Chandrashekar R, Stillman BA, Tyrrell P, Thatcher B, et al. Development of antibodies to and PCR detection of Ehrlichia spp in dogs following natural tick exposure. Vet Microbiol. 2014;173:379-84.

36. Csokai J, Klas EM, Heusinger A, Müller E. Vorkommen von Ehrlichia canis bei in Deutschland lebenden Hunden sowie Vergleich direkter und indirekter Diagnostikmethoden. Tierärztliche Prax Kleintiere. 2017:45:301-7

37. Neer TM, Breitschwerdt EB, Greene RT, Lappin MR. Consensus statement on ehrlichial disease of small animals from the infectious disease study group of the ACVIM. J Vet Intern Med. 2002;16:309-15.

38. Waner T, Harrus S, Jongejan F, Bark H, Keysary A, Cornelissen AWCA. Significance of serological testing for ehrlichial diseases in dogs with special emphasis on the diagnosis of canine monocytic ehrlichiosis caused by Ehrlichia canis. Vet Parasitol. 2001:91:1-15.

39. Wardrop KJ, Birkenheuer A, Blais MC, Callan MB, Kohn B, Lappin MR, et al. Update on canine and feline blood donor screening for blood-borne pathogens. J Vet Intern Med. 2016;30:15-35.

40. labal Z, Rikihisa Y. Reisolation of Ehrlichia canis from blood and tissues of dogs after doxycycline treatment. J Clin Microbiol. 1994;32:1644-9.

41. Neer TM, Eddlestone SM, Gaunt SD, Corstvet RE. Efficacy of enrofloxacin for the treatment of experimentally induced Ehrlichia canis infection. J Vet Intern Med. 1999;13:501-4.

42. Raskin RE, Messick JB. Bone marrow cytologic and histologic biopsies: indications, technique, and evaluation. Vet Clin North Am Small Anim Pract. 2012:42:23-42.

43. Boothe HW. Current concepts in hepatobiliary surgery. Vet Clin North Am Small Anim Pract. 2015:45:463-75.

44. Martineau MMC. Multicentric canine lymphoma in a 12-year-old keeshond: chemotherapy options. Can Vet J. 2002;43:709-11.

45. Rose HL, Dewey CA, Ely MS, Willoughby SL, Parsons TM, CoxV, et al. Comparison of eight methods for the extraction of Bacillus atrophaeus spore DNA from eleven common interferents and a common swab. PLoS One. 2011;6:e22668.

46. Mathios ME, Konstantina TN. Canine monocytic ehrlichiosis: an update on diagnosis and treatment. Acta Vet Brno. 2017;67:299-317.

47. Martínez AM, Arraga-Alvarado CM, Triana-Alonso FJ, Ruiz C. Gutiérrez GCN [A serological and molecular survey of Ehrlichia canis in dogs from a community in Aragua state, Venezuela]. Rev Investig Vet Perú. 2015;26:648-56.

48. Harrus S, Waner T, Keysary A, Aroch I, Voet H, Bark H. Investigation of splenic functions in canine monocytic ehrlichiosis. Vet Immunol Immunopathol. 1998;62:15-27.

49. Movilla R, Altet L, Serrano L, Tabar MD, Roura X. Molecular detection of vector-borne pathogens in blood and splenic samples from dogs with splenic disease. Parasit Vectors. 2017;10:131.

50. Theodorou K, Mylonakis ME, Siarkou VI, Leontides L, Koutinas AF, Koutinas CK, et al. Efficacy of rifampicin in the treatment of experimental acute canine monocytic ehrlichiosis. J Antimicrob Chemother. 2013;68:1619-26.

51. Lanza-Perea M, Zieger U, Qurollo BA, Hegarty BC, Pultorak EL, Kumthekar $\mathrm{S}$, et al. Intraoperative bleeding in dogs from Grenada seroreactive to Anaplasma platys and Ehrlichia canis. J Vet Intern Med. 2014;28:1702-7.

52. Hildebrandt PK, Huxsoll DL, Walker JS, Nims RM, Taylor R, Andrews M. Pathology of canine ehrlichiosis (tropical canine pancytopenia). Am J Vet Res. 1973;34:1309-20.

53. Mylonakis ME, Kritsepi-Konstantinou M, Dumler JS, Diniz PPVP, Day MJ, Siarkou VI, et al. Severe hepatitis associated with acute Ehrlichia canis infection in a dog. J Vet Intern Med. 2010;24:633-8.

54. Trapp SM, Dagnone AS, Vidotto O, Freire RL, Amude AM, de Morais HSA. Seroepidemiology of canine babesiosis and ehrlichiosis in a hospital population. Vet Parasitol. 2006;140:223-30.

55. Waner T, Harrus S. Canine monocytic ehrlichiosis-from pathology to clinical manifestations. Isr J Vet Med. 2013;68:12-8.

56. Silaghi C, Santos AS, Gomes J, Christova I, Matei IA, Walder G, et al. Guidelines for the direct detection of Anaplasma spp in diagnosis and epidemiological studies. Vector Borne Zoonotic Dis. 2017;17:12-22.

\section{Publisher's Note}

Springer Nature remains neutral with regard to jurisdictional claims in published maps and institutional affiliations. 